\title{
Trends of 3D bioprinting in vascular surgery
}

\section{Tendencias en bioimpresión 3D en cirugía vascular}

\author{
Adriana Torres-Machorro ${ }^{1}$, Christopher Ruben-Castillo², Esteban Ortega-Hernández ${ }^{3}$, Ramses Galaz-Mendez ${ }^{4}$, \\ Paola Ulacia-Fores ${ }^{4,5}$, Sabsil Lopez-Rocha², Paula Leal-Anaya ${ }^{2}$ y Carlos A. Hinojosa2* \\ ${ }^{1}$ Service de Chirurgie Viscerale et Vasculaire, Groupement Hospitalier de Territoire Grand Paris Nord-Est GHI Le Raincy-Montfermeil, Montfermeil, \\ Francia; ${ }^{2}$ Servicio de Angiología y Cirugía Vascular, Departamento de Cirugía, Instituto Nacional de Ciencias Médicas y Nutrición Salvador Zubirán, \\ Ciudad de México, México; ${ }^{3}$ Centre of Microvascular Research, The William Harvey Research Institute, Barts and The London School of Medicine, \\ Queen Mary University of London, London, United Kingdom; ${ }^{4}$ Departamento de Biomédica, GS Biomedical, Hermosillo, Sonora, México; ${ }^{5}$ Department \\ of Mechanical Engineering, McGill University, Montreal, Canada
}

\begin{abstract}
Nowadays, surgical planning is recognized as one of the most useful applications of three-dimensional (3D) printing. It has been demonstrated that $3 D$ models may assist to overcome the surgical challenges of complex vascular anatomy and improve the endovascular skills required in certain procedures. Therefore, reproducing a patient based anatomical 3D model act as a tool for individualized preoperative planning and decision making with a direct positive impact in the clinical outcomes. Another interesting field concerning vascular surgery and bioprinting, is the possibility of developing a variety of prosthetic devices for treating vascular disease. The main objective is to overcome biocompatibility disadvantages of prosthesis made from synthetic fabrics among other shortcomings. These may include, long manufacturing times and the high costs of an individualized prosthetic device, challenges faced when an autologous vein is not available. Unfortunately, cases requiring this sophisticated management are usually faced in the context of emergency care with a limited number of therapeutic options and a high mortality rate. Understanding the complexity of vessels biology; such as the interactions between each layer of the vessel wall, is extremely important for making a 3D-printed vessel which could, in the close future, simulate a real human vessel. Achieving this would mean more availability and in consequence, cost reduction for treating complex vascular disease. These benefits would be reflected not only in lowering medical and hospital expenses, but also in the morbidity and mortality related to the surgical procedure.
\end{abstract}

Key words: 3D vascular models. 3D vessel bioprinting. Biocompatibility. Vascular prosthetic device.

\section{Resumen}

La planeación quirúrgica es una de las principales y más útiles aplicaciones que ha aportado la impresión tridimensional (3D). Se ha estudiado que los modelos 3D pueden ayudar a superar los retos quirúrgicos derivados de una anatomía aórtica compleja, además de perfeccionar las técnicas endovasculares convencionales. Por lo tanto, la producción de un modelo 3D basado en la anatomía única de cada paciente actúa como una herramienta preoperatoria individualizada beneficiosa para la planeación y la toma de decisiones quirúrgicas, con un efecto positivo directo en los resultados postoperatorios. Además, existe la posibilidad de desarrollar una variedad de prótesis para el tratamiento de diversas patologías del sistema vascular cuando no existe una vena autóloga disponible. El objetivo principal es superar las desventajas de la biocompatibilidad de los materiales que conforman las prótesis vasculares sintéticas. Otros inconvenientes son el tiempo prolongado de fabricación y los altos costos de una prótesis individualizada. Desafortunadamente, los casos que requieren este manejo sofisticado cuentan con un número limitado de opciones terapéuticas y, por lo tanto, conllevan una alta mortalidad. La comprensión de la fisiología de un www.RMAngiologia.com 0377-4740/C 2019 Sociedad Mexicana de Angiología y Cirugía Vascular y Endovascular, A.C. Publicado por Permanyer. Éste es un artículo open access bajo la licencia CC BY-NC-ND (http://creativecommons.org/licenses/by-nc-nd/4.0/).
} 
Rev Mex Angiol. 2019;47

vaso sanguíneo es de extrema importancia para la impresión de un vaso sanguíneo 3D. Este último pudiera en el futuro próximo simular un vaso sanguíneo humano. Alcanzar esta meta significaría mayor disponibilidad de injertos y, en consecuencia, una reducción de costos en el tratamiento, así como en la morbilidad y mortalidad asociadas al procedimiento quirúrgico.

Palabras clave: Modelos vasculares 3D. Impresión vascular 3D. Biocompatibilidad. Prótesis vascular sintética.

\section{Introduction}

The structure of arteries and veins is quite similar but can be distinguished by the tunica thickness and the cellular and protein compositions at each layer. In addition to this, each layer plays a different role in the interaction and response to environmental factors. In table 1 we depict a brief summary of the structure and function of the vascular system.

Overview of vascular surgery: Vascular surgery manages the diagnosis, medical treatment, longitudinal management and/or reconstructive treatment of diseases from the peripheral blood vessels, including arteries, veins and lymphatics. Certain blood flow conditions are required to achieve normal blood circulation. These concerns the integrity of the blood clotting system and the vessel wall signaling systems involving the immunity, inflammation, cell repair and proliferation. However, when disturbances occur in either component, vascular disorders such as occlusive, aneurysmal, inflammatory disease, compressive syndromes or trauma become evident. Clinical evaluation, non-invasive diagnostic testing (duplex ultrasonography, computed tomographic angiography CTA) and invasive diagnostic testing (angiography) are utilized for accurate diagnosis of blood vessel alterations due to lumen narrowing or wall degeneration. Several surgical reconstruction techniques employ different devices to overcome major complications associated with vascular disease such as death, ischemia and limb loss. Examples of vascular disease and its treatment are included in table 2. Although the availability of novel endovascular techniques for all areas of vascular surgery and advances in cell therapy and regenerative medicine, techniques that substitute the damaged vessel such as bypass, still play an important role in vascular disease. Nonetheless, both are mainly based in the utilization of prosthetic synthetic devices. The most common graft used is the autologous great saphenous vein consequently to its improved permeability, bio-compatibility and long-term durability. However, limits to this vein are its unavailability or unsuitability by reason of its small diameter or varicosity. As a result, the production of new synthetic non-degradable prosthetic devices is encouraged with: micro porous expanded polytetrafluoroethylene, polyurethane or dacron (polyester); in some cases, coated with drug eluting properties (as heparin or paclitaxel) in order to prevent late thrombosis (Table 3). Anatomical location and flow rate are determinants of success in these procedures among other issues such as anastomotic intimal hyperplasia and graft infection susceptibility ${ }^{1}$. Increased longevity came along with an increased incidence of vascular disease. Therefore, demand of vascular grafts has raised, including those $<6 \mathrm{~mm}$ (small-diameter) for the replacement of diseased coronary and below the knee vessels ${ }^{2}$. Despite significant effort by industrial and academic research groups over the past half-century, a durable, synthetic, small-diameter vascular graft does not exist by reason of acute thrombogenicity of the graft, anastomotic intimal hyperplasia, aneurysm formation, infection, and progression of atherosclerotic disease. In spite of this drawbacks, success has been achieved when replacing large caliber arteries such as the thoracic and abdominal aorta, the aortic arch vessels, iliac, and common femoral arteries ${ }^{3}$. Attempts to address these failure mechanisms and the complete absence of a small-diameter conduit have led to collaborative interactions among vascular surgeons, material scientists, biologists, and engineers. Novel materials with improved mechanical responses continue to be synthesized, and new surface engineering schemes along with systemic antithrombotic medications have been used to reduce the risk of thrombus formation.

Recently, advances in 3-D bioprinting propose another option to overcome the following limitations of vascular grafts:

- Inability of current prostheses to minimize the activation of prothrombotic responses through antithrombotic mechanisms localized to the endothelium.

- Requirement of prosthesis removal in cases of graft infection, as a result of the assembly of a bacterial biofilm on the graft, that protects bacteria from immune response and antibiotics. This is associated with $50 \%$ amputation rate and $25-75 \%$ mortality rate.

- Optimization of graft porosity

- Absence of protein transport to a surface by convection and diffusion. 
Table 1. Structure and function of vascular vessels

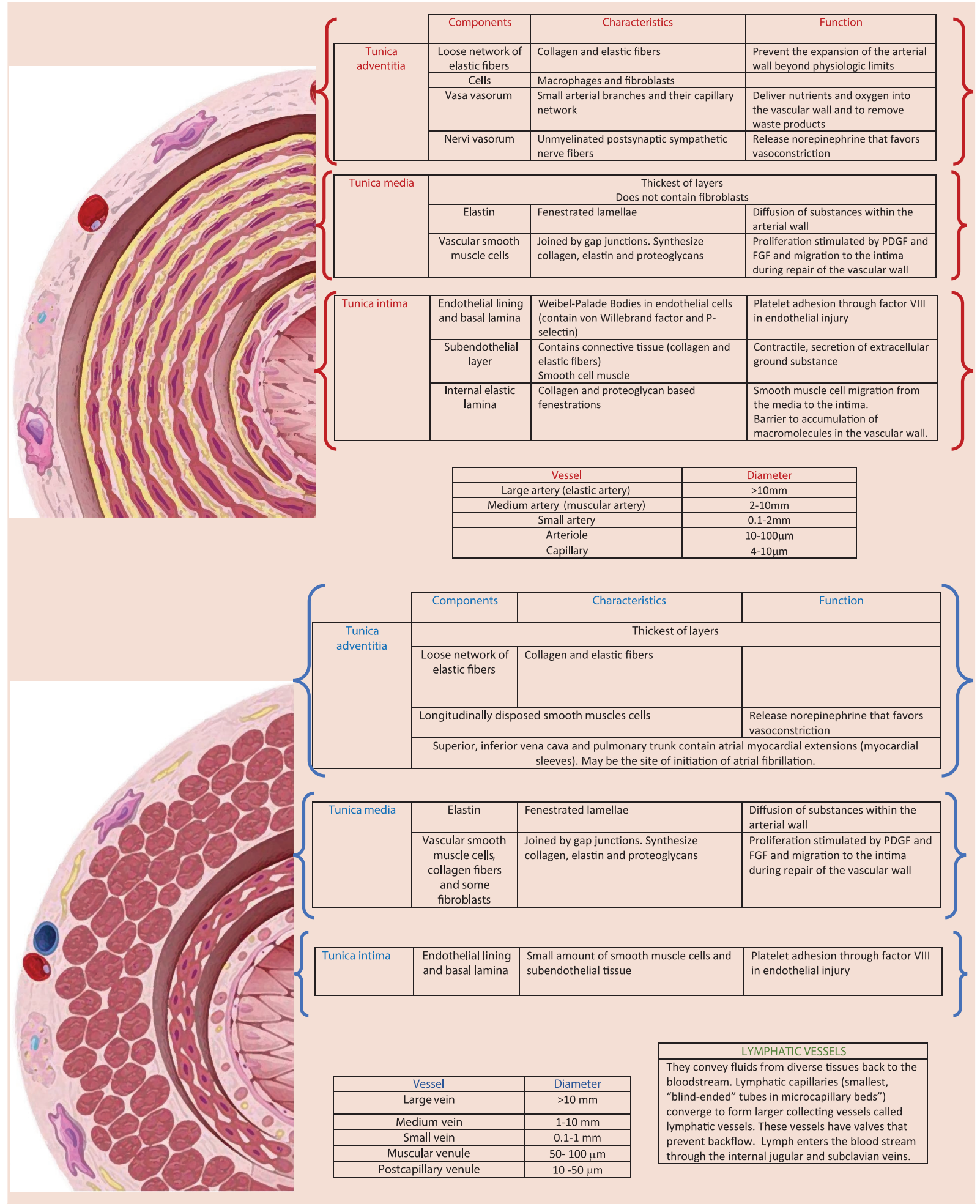

Data from Ross, et al. $2016^{4}$

- Minimizing the activation of coagulation and complement cascades promoted by the contact of blood with the graft's artificial surface:
- The complement cascade stimulates the inflammatory response as a prelude to platelet activation, monocyte and neutrophil infiltration, all which 
Table 2. Vascular diseases and treatment options

\begin{tabular}{|c|c|c|c|c|}
\hline Blood vessel & Disease Type & Physiopathology & Complication & Interventional Treatment \\
\hline \multirow[t]{3}{*}{ Arterial } & $\begin{array}{l}\text { Peripheral artery } \\
\text { disease }\end{array}$ & $\begin{array}{l}\text { Peripheral artery narrowing or } \\
\text { occlusion mainly due to } \\
\text { atherosclerosis }\end{array}$ & Gangrene and limb loss & $\begin{array}{l}\text { Venous bypass } \\
\text { Prosthetic bypass } \\
\text { Endovascular treatment* }\end{array}$ \\
\hline & $\begin{array}{l}\text { Carotid artery } \\
\text { disease }\end{array}$ & $\begin{array}{l}\text { Narrowing of the carotid artery } \\
\text { due to inflammation and } \\
\text { atherosclerosis }\end{array}$ & $\begin{array}{l}\text { Stroke or transient } \\
\text { ischemic attack }\end{array}$ & $\begin{array}{l}\text { Endarterectomy + synthetic } \\
\text { patch } \\
\text { Endovascular treatment* }\end{array}$ \\
\hline & $\begin{array}{l}\text { Abdominal aortic } \\
\text { aneurysm }\end{array}$ & $\begin{array}{l}\text { Abnormal growth of the aortic } \\
\text { diameter due to a degenerative } \\
\text { process of the vessel wall. }\end{array}$ & Rupture and death & $\begin{array}{l}\text { Aortic open reconstruction with } \\
\text { synthetic or autologous (aortic } \\
\text { infection) graft } \\
\text { EVAR }^{* *}\end{array}$ \\
\hline \multirow[t]{2}{*}{ Venous } & $\begin{array}{l}\text { Chronic venous } \\
\text { insufficiency }\end{array}$ & $\begin{array}{l}\text { Damaged vein valves and/or } \\
\text { venous wall impeding venous } \\
\text { blood return. }\end{array}$ & $\begin{array}{l}\text { Limb venous ulcer and } \\
\text { infectious complications }\end{array}$ & $\begin{array}{l}\text { Compression stockings } \\
\text { Endovascular ablation methods }\end{array}$ \\
\hline & $\begin{array}{l}\text { Deep vein } \\
\text { thrombosis }\end{array}$ & $\begin{array}{l}\text { Vein occlusion due to an } \\
\text { hypercoagulable state }\end{array}$ & $\begin{array}{l}\text { Post-phlebitic syndrome } \\
\text { Compartment syndrome }\end{array}$ & $\begin{array}{l}\text { Compression stockings + iliac } \\
\text { vein stenting }\end{array}$ \\
\hline \multirow[t]{2}{*}{ Lymphatic } & $\begin{array}{l}\text { Primary } \\
\text { lymphedema }\end{array}$ & $\begin{array}{l}\text { Absence or anomaly of certain } \\
\text { lymph vessels at birth }\end{array}$ & Soft tissue infections & $\begin{array}{l}\text { Compression stockings } \\
\text { Reconstructive Surgery }\end{array}$ \\
\hline & $\begin{array}{l}\text { Secondary } \\
\text { lymphedema }\end{array}$ & $\begin{array}{l}\text { Blockage or interruption of the } \\
\text { lymphatic system due to } \\
\text { surgery, infection or malignancy. }\end{array}$ & Soft tissue infections & $\begin{array}{l}\text { Compression stockings } \\
\text { Reconstructive surgery }\end{array}$ \\
\hline $\begin{array}{l}\text { Vascular } \\
\text { access }\end{array}$ & $\begin{array}{l}\text { End stage renal } \\
\text { disease }\end{array}$ & $\begin{array}{l}\text { Renal function below } 15 \% \text { of its } \\
\text { normal function requiring } \\
\text { dialysis }\end{array}$ & $\begin{array}{l}\text { Anemia, hypertension, } \\
\text { bone disease and death }\end{array}$ & $\begin{array}{l}\text { Autologous arteriovenous fistula } \\
\text { Prosthetic arteriovenous fistula }\end{array}$ \\
\hline
\end{tabular}

*Endovascular treatments refer to angioplasty, stenting and/or atherectomy (limited to arterial disease) procedures, which may vary according to the vascular disease.

**Endovascular aneurism repair.

finally lead to neointimal hyperplasia and inhibition of graft lumen endothelization.

- The coagulation cascade is activated through the interaction with blood and a tissue-material interface in addition to the activation through tissue factor expressed at the anastomotic site after injury.

- Highly inefficient migration of endothelial cells from the perianastomotic areas leading to neointimal formation by promoting smooth muscle cells (SMC) proliferation a few centimeters from the anastomoses and a little coverage of the mid portion.

- Compliance mismatch between a relatively stretchable host vessel and stiff graft leads to a region of excessive mechanical stress that may contribute to anastomotic intimal hyperplasia. This occurs by stimulation of perianastomotic SMC exposed to anomalous cyclical strain forces and to mitogens released by activated platelets trapped by anastomotic flow disturbance. Although compliant polyurethane grafts offer a greater degree of compliance match similar to the artery in comparison to ePTFE and Dacron, they are still stiffer and less compliant than the artery 5 .

- Finally, the polyether-based segmented urethanes that compose the synthetic graft are susceptible to oxidation reactions, catalyzed by enzymes released during the inflammatory response, which can lead to surface fissuring and material degradation.

Vascular 3D-bioprinting potentially offers a solution to the several limitations faced with the conventional therapeutic options available nowadays.

\section{Bio-fabrication and bioprinting of blood vessels}

The typical process for bioprinting 3D tissues involves several steps. First of all, medical imaging is used to provide the information on the $3 \mathrm{D}$ structure desired for printing. Either X- ray, ACT or magnetic resonance imaging may be useful for these purposes. (Fig. 1A) Due to the complex layer-by-layer precise positioning of biological materials, biochemical and living cells it is important to increase the distinctiveness of biological structures when imaging. Fine spatial 
Table 3. Types of prosthetic devices commonly used

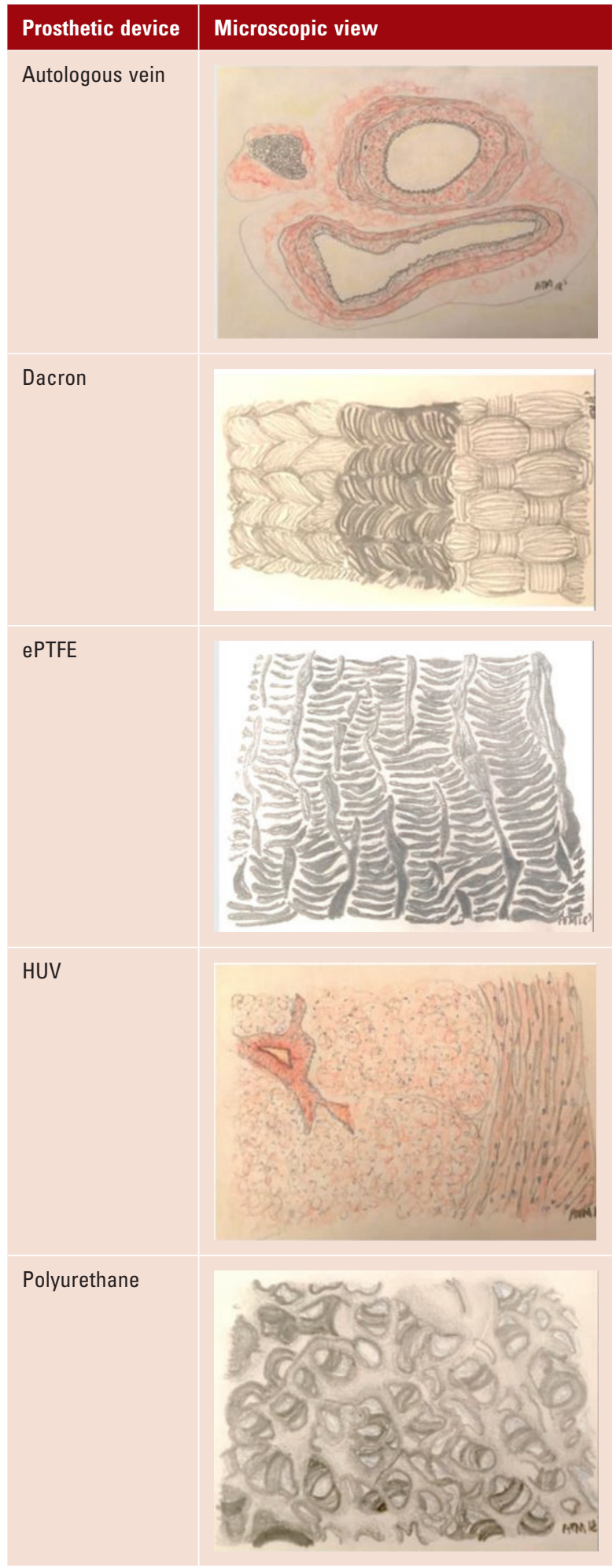

control of the placement of functional components is required to fabricate $3 \mathrm{D}$ structures. It is highly recomended then, the use of contrast agents, such as barium, iodine, iron oxide, gadolinium or metalloproteins ${ }^{6}$ to potentially restore biological function.

After 3D images are obtained, we must decide the approach that fits better for designing the structure selected (Fig. 1B). Biomimicry, tissue self-assembly and mini-tissue building blocks are examples of design approaches used. Combined and complex strategies are required to print a biological structure with multiple functional, structural and mechanical components and properties $^{6}$.

Biomimicry seeks to analogously reproduce cellular and extracellular components tissues or organs ${ }^{7}$ resembling the disposition of the functional and supporting cells, however, the composition of the extracellular matrix (ECM) and interacting biological forces participating in the microenvironment, add difficulty to the process.

Autonomous self-assembly approach uses embryonic organ development as a guide for tissue self-organization. In this case, early cellular components of developing tissues, produce their own ECM components. With appropriate cell signaling, autonomous organization and patterning happen to yield the desired biological micro-architecture and function ${ }^{8}$. Obvious limitations to this technique includes the deep knowledge involved in embryonic tissue genesis and organogenesis that enable environment manipulation of embryonic developmental mechanisms.

Finally, mini-tissues seek to comprise functional small building blocks of a greater tissue. This can be fabricated and assembled into a larger construct by rational design, self-assembly or a combination of both. The former works are based on two major strategies: first, self-assembling cell spheres (similar to mini-tissues) are assembled into a macro-tissue using biologically inspired design and organization ${ }^{9,10}$; second, accurate, high-resolution reproductions of a tissue unit are designed and then allowed to self-assemble into a functional macrotissue. Examples of these approaches include the self-assembly of vascular building blocks to form branched vascular networks ${ }^{11}$.

After the initial steps in bioprinting such as imaging and designing are completed, materials and cells are meant to be chosen (Figs. 1C-D).

The ideal material selected for bioprinting, is meant to form the scaffold for the cells and expected to meet certain characteristics. It should be printable and biocompatible. This facilitates handling and deposition by the bioprinter and contributes to the biological, immunological and functional material interaction with the host. Other important features are structural and mechanical properties which 


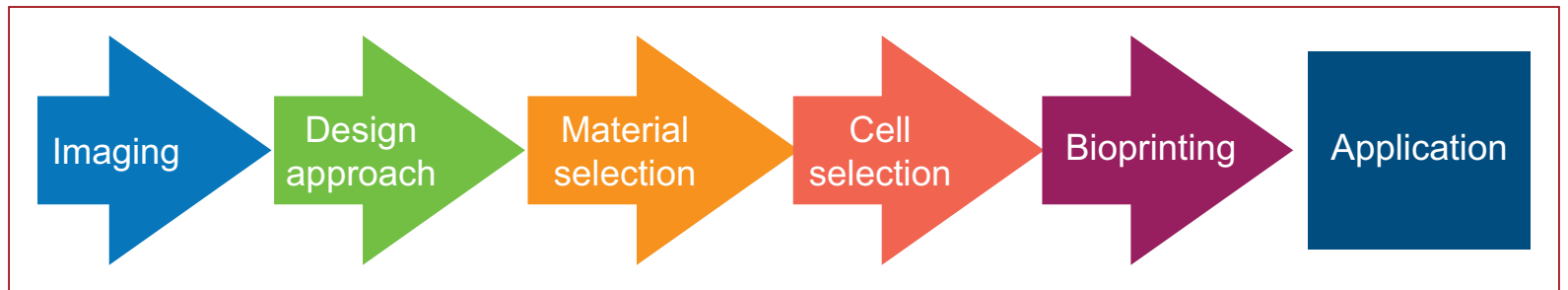

Figure 1. The process of 3D bioprinting.

determine rigidity and strength of the material for cell compatibility along with the biomimicry, which relates to the capacity to imitate the endogenous constituents. Materials should also match the ability of cells to produce their own ECM coped with its degradation rate. The metabolism of degradation byproducts should be non-toxic and also suitable for swelling or contractile properties (degradation kinetics and byproducts characteristic).

Materials available for bioprinting include: synthetic and natural polymers and ECM. The construction of a scaffold that mimics the native the mechanical properties of the vascular tissue and that also promotes cell growth, inhibits thrombogenicity and facilitates extracellular matrix production is still underway ${ }^{12}$. Examples of materials studied for scaffolding in tissue engineering are depicted in figure 2.

On the other hand, cells sources are to be decided as well (Fig. 1D). This comprises the selection of the primary functional cell types along with the other cells that provide:

- The supportive, structural or barrier functions involved in vascularization or,

- The adequate environment for cell differentiation and maintenance.

Cells are expected also to meet some requirements: Initially, they should be able to expand into sufficient numbers for maintaining viability of the construct. The bio printed construct should also maintain cellular homeostasis, self-renewal and respond to tissue damage or injury after being transplanted.

Stem cells, promising for bioprinting goals, proliferate in an undifferentiated but multipotent state which can generate multiple functional cell types. Perinatal stem cells for amniotic fluid or placenta, embryonic stem cells and adult stem cells for bone marrow and fat are some examples $^{13}$. This cells must be robust enough to support the toxins, enzymes, non-physiological pH, shear stress and pressure during the printing process. Stem cells used for tissue engineering of blood vessels are shown in table $4^{14}$. Successful blood vessel construction through tissue engineering approach has focused in generating a functional smooth muscle layer due to its role in homeostasis and physiological function of blood vessels. Nevertheless, alternative cells have been explored because of its limited proliferation ability and the contractile phenotype loss of mature-differentiated SMCs ${ }^{15}$.

Materials and cells affect the tissue and organ design. This occurs because its characteristics determine also the bioprinting system capable of printing the material and the design selected. Multiple technologies are available for bioprinting, being the most influential the inkjet, microextrusion and laser-assisted printing ${ }^{16}$.

The difference between the bioprinting systems relies on the way they deposit the material, either in a continuous bead or into short interrupted or defined spaces. The ultimate has the advantage to allow the deposit of multiple materials. The variety of bioprinting systems is resumed in table 5 .

The most frequently type of printer employed for either biological and non-biological applications is inkjet bioprinting. Biological material is used as an ink that is dropped on demand by an electronically controlled elevator stage to provide control of the $z$ axis ${ }^{17}$. Drops of liquid are ejected by means of thermal or acoustic energy, onto a substrate which can support or form part of the final construct. Limitations due to an excessive force required to eject drops may occur with high viscosity materials. When multiple ejectors are combined it is possible to print simultaneously multiple cell and material types ${ }^{18}$.

In contrast, microextrusion brioprinting, yields a continuous bed of material rather than droplets. Small beads of protuberant material are robotically controlled and conformed in two dimensions. The depositing process of material into the subtract is held by a microextrusion head. These bioprinters are the most common and affordable for non-biological printing, they are also compatible with a myriad of materials such as hydrogels, biocompatible copolymers and cell spheroids. This system utilizes pneumatic or mechanical (piston or screw) methods for dispensing materials ${ }^{19}$. 


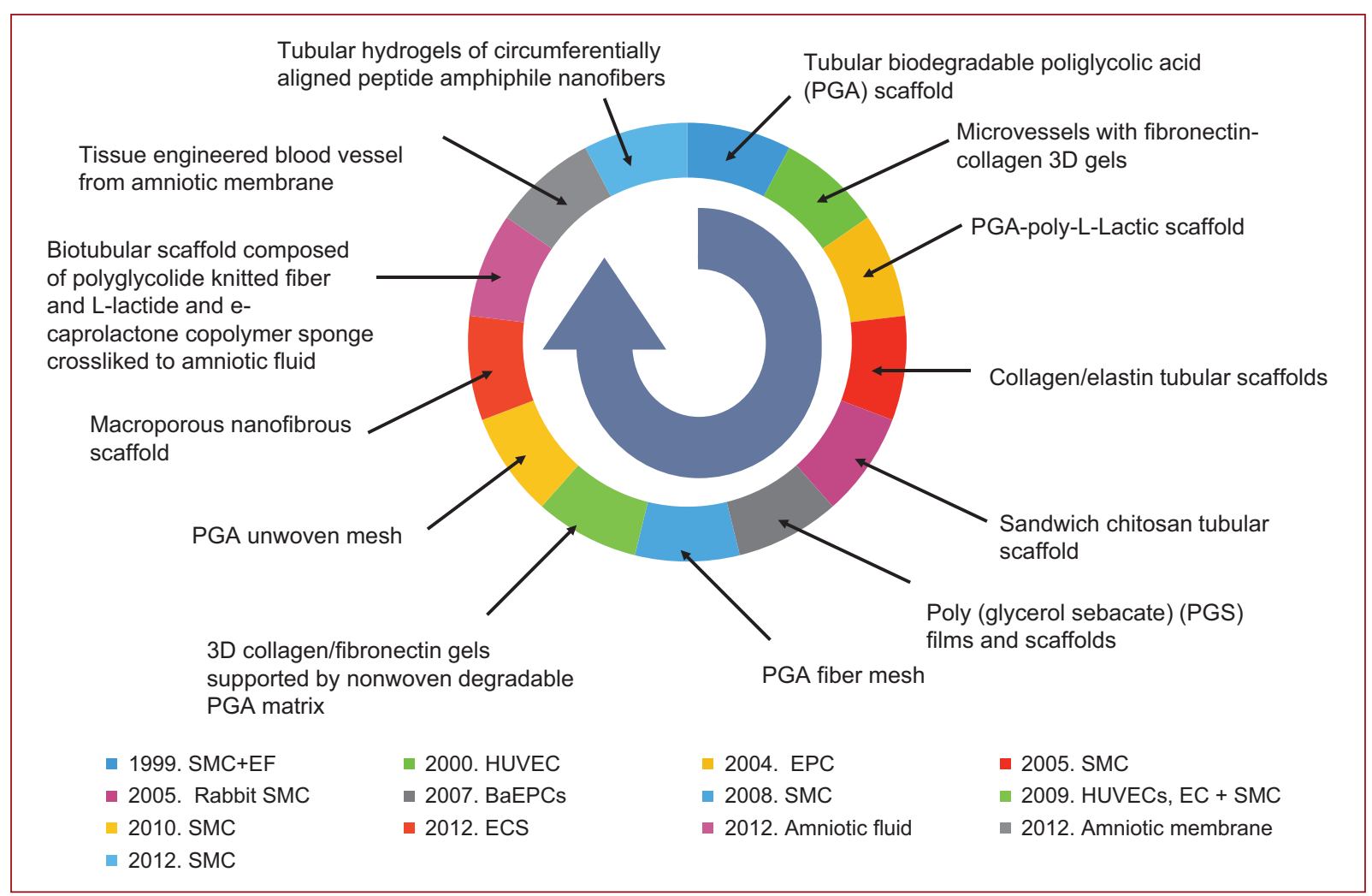

Figure 2. Cells and scaffolds engineered in chronological order (data from Nemeno-Guanzon, et al. 201214).

The high resolution of microextrusion systems permit to accurately fabricate complex structures with very high cell densities. Higher viscosity materials provide the structural support for a printed construct whereas lower viscosity materials, the environment for maintaining cell viability and function ${ }^{20}$.

Laser-assisted bioprinting ( $L A B)$ is a nozzle free (avoids clogging of cells/materials) bioprinter which generates a high-pressure bubble that propels the materials containing cells towards the collector substrate. Focused laser pulses on the absorbing layer of the ribbon to initiate the printing process. Time consuming preparation is often required for each printed cell or hydrogel type, but many advantages related to its wide compatibility range of viscosities, high cell density deposits and printing velocity, poses it as an attractive tool ${ }^{21-27}$.

Most strategies had generally revolved around scaffold based engineering where by cells are usually encapsulated in bio inks. Scaffolds are not only the support for cell growth, but also resemble the ECM of the native microenvironment.

Specifically speaking about blood vessel printing (Fig. 1F), there are currently three major approaches for fabrication of blood vessels: perfusable scaffolds, self-assembly of vessels and scaffold free bio fabrication of autonomous vascular structures.

1. Perfusable scaffolds: The extrusion-based technique is the most straightforward to produce a network of interconnected channels within the scaffold. This technique deposits during one extrusion session, various cell types like endothelial cells or micro-vessels fragments in the bio ink, therefore promoting high viability vascular network formations ${ }^{28}$. This bioprinting technique can be accomplished either by direct or indirect extrusion.

A. Direct extrusion requires a precise control of temperature and pressure to maintain hydrogel printability; it uses a bottom-up layer-by-layer dual-nozzle bioprinting approach to print complex hybrid constructs with distinct spatial organizations. This is possible with a proper bioprinter, crosslinking methods and differentiation induction which maintain structural integrity for more than two weeks along with cellular growth, proliferation and differentiation. Recent efforts have proposed to print the scaffold into a cross linking solution at the same time. This could be 
Table 4. Stem cells for tissue engineering of blood vessels

\begin{tabular}{|c|c|c|c|c|c|}
\hline Stem cell & $\begin{array}{l}\text { Differentiation } \\
\text { potential }\end{array}$ & Viability & Harvesting & Proliferation & Other Advantages \\
\hline $\begin{array}{l}\text { Mesenchymal } \\
\text { Stem } \\
\text { Cells (MSCs) }\end{array}$ & Pluripotent & $\begin{array}{l}\text { Long-term } \\
\text { viability } \\
\text { Self-renewal } \\
\text { capacity }\end{array}$ & $\begin{array}{l}\text { Complicated } \\
\text { Low frequencies of } \\
\text { existence }\end{array}$ & $\begin{array}{l}\text { Time consuming } \\
\text { expansion }\end{array}$ & \\
\hline $\begin{array}{l}\text { Adipose } \\
\text { derived stem } \\
\text { cells (ASCs) }\end{array}$ & $\begin{array}{l}\text { Superior } \\
\text { multi-differentiation } \\
\text { potential } \\
\text { Multipotency is } \\
\text { independent of the } \\
\text { donor's age }\end{array}$ & $\begin{array}{l}\text { Susceptible to } \\
\text { apoptosis } \\
\text { during isolation }\end{array}$ & $\begin{array}{l}\text { Easily acquired with } \\
\text { minimally invasive } \\
\text { technique } \\
\text { Lower donor-site } \\
\text { morbidity (abundant } \\
\text { and practical) }\end{array}$ & $\begin{array}{l}\text { Rapid in vitro } \\
\text { expansion } \\
\text { Requires growth } \\
\text { factors for cell } \\
\text { expansion }\end{array}$ & $\begin{array}{l}\text { Secretes several } \\
\text { angiogenesis related } \\
\text { factors and therefore } \\
\text { induces angiogenesis }\end{array}$ \\
\hline $\begin{array}{l}\text { Embryonic } \\
\text { stem } \\
\text { cells (ESCs) }\end{array}$ & $\begin{array}{l}\text { Pluripotent (may } \\
\text { differentiate to SMC) }\end{array}$ & $\begin{array}{l}\text { Self-renewal } \\
\text { based in the } \\
\text { origin for ESCs }\end{array}$ & $\begin{array}{l}\text { Requires embryos } \\
\text { that develop from } \\
\text { eggs fertilized } \\
\text { in vitro }\end{array}$ & $\begin{array}{l}\text { Low induction } \\
\text { efficiency } \\
\text { Low SMC purity }\end{array}$ & \\
\hline $\begin{array}{l}\text { Endothelial } \\
\text { progenitor } \\
\text { cells (EPCs) }\end{array}$ & $\begin{array}{l}\text { Totipotent. Unknown } \\
\text { in vivo EPC } \\
\text { differentiation and } \\
\text { migration signals and } \\
\text { homing to the sites of } \\
\text { injured endothelium } \\
\text { of extravascular area }\end{array}$ & $\begin{array}{l}\text { EPCs from high } \\
\text { risk } \\
\text { cardiovascular } \\
\text { patients have } \\
\text { higher rates of } \\
\text { in vitro } \\
\text { senescence }\end{array}$ & $\begin{array}{l}\text { Harvested prenatally } \\
\text { and non-invasively }\end{array}$ & $\begin{array}{l}\text { Exponential } \\
\text { proliferation rate }\end{array}$ & $\begin{array}{l}\text { Involved in hemostasis, } \\
\text { angiogenesis and } \\
\text { arterial injury and } \\
\text { endothelium repair. } \\
\text { Promotes } \\
\text { neovascularization in } \\
\text { ischemic tissue, coating } \\
\text { of vascular grafts, } \\
\text { seeding hybrid grafts }\end{array}$ \\
\hline $\begin{array}{l}\text { Bone marrow } \\
\text { cells (BMCs) }\end{array}$ & $\begin{array}{l}\text { Multipotent. Capable } \\
\text { of differentiation } \\
\text { along several } \\
\text { lineages (osteoblasts, } \\
\text { chondrocytes, } \\
\text { adipocytes, myocytes, } \\
\text { myofibroblasts, } \\
\text { endothelial cells) }\end{array}$ & $\begin{array}{l}\text { Readily } \\
\text { accessible } \\
\text { autologous cell } \\
\text { source }\end{array}$ & $\begin{array}{l}\text { Aspiration is less } \\
\text { invasive and } \\
\text { associated with } \\
\text { much lower } \\
\text { morbidity at the } \\
\text { donor sites }\end{array}$ & $\begin{array}{l}\text { Expand in culture up } \\
\text { to six fold and their } \\
\text { biological functions } \\
\text { are not altered by } \\
\text { aging }\end{array}$ & $\begin{array}{l}\text { Improve patency in } \\
\text { tissue-engineered } \\
\text { small-diameter } \\
\text { vascular grafts } \\
\text { Potential to regenerate } \\
\text { vascular tissues }\end{array}$ \\
\hline $\begin{array}{l}\text { Human } \\
\text { umbilical cord } \\
\text { vein } \\
\text { endothelial } \\
\text { cells (HUVEC) }\end{array}$ & Multipotent & $\begin{array}{l}\text { Viability of } 70 \% \\
\text { in commercially } \\
\text { available } \\
\text { HUVEC }\end{array}$ & $\begin{array}{l}\text { Low cost, and } \\
\text { simple techniques } \\
\text { for isolating them } \\
\text { from umbilical } \\
\text { cords, which are } \\
\text { normally resected } \\
\text { after childbirth }\end{array}$ & $\begin{array}{l}\text { Time consuming } \\
\text { isolation } \\
\text { Low but easy } \\
\text { proliferative capacity } \\
\text { Cell culture includes } \\
\text { risk of infection and } \\
\text { requires exogenous } \\
\text { growth factor }\end{array}$ & $\begin{array}{l}\text { Prevent platelet } \\
\text { adhesion } \\
\text { Have reproductible and } \\
\text { enhanced angiogenesis } \\
\text { capacity (in vitro) } \\
\text { Important in } \\
\text { endothelization after } \\
\text { transplantation } \\
\text { Prone to form } \\
\text { capillaries }\end{array}$ \\
\hline
\end{tabular}

SMC: smooth muscle cells.

Data from Nemeno-Guanzon, et al. $2012^{14}$.

accomplished by using a coaxial nozzle which concurrently prints hollow channel vessel-like cellular micro-fluidic channel. The objective is to fabricate scaffolds with hollow channels and large scale constructs, however, difficulties are faced to maintain hydrogel reproducibility and visco-elasticity which tends to vary over time and between batches $^{29}$. A circular biomimetic liver construct with seven vascular channels within the construct illustrates this approach ${ }^{30}$.
B. Indirect extrusion uses sacrificial inks for biofabricating well defined microchannels, unfortunately, these inks tend to be associated with cytotoxic by-products after post dissolution treatment of the sacrificial ink. Nonetheless, this disadvantage may be overcome by novel artificial or naturally derived sacrificial inks, many criterions must be met in order to be joined to the main bioink correspondent to its printing compatibility under ambient condition. Most importantly, cells in the bioink and its structural 
Table 5. Bioprinting systems (according to Nemeno-Guanzon, et al. 201214)

\begin{tabular}{|c|c|c|c|}
\hline & Laser assisted & Microextrusion & Inkjet \\
\hline Costs & ++++ & ++ & + \\
\hline Preparation time & ++++ & ++ & + \\
\hline Print speed & $++/++++$ & + & ++++ \\
\hline $\begin{array}{l}\text { Resolution/droplet } \\
\text { size (Micrometer) }\end{array}$ & + & $+/+++$ & ++ \\
\hline Material viscosities (mPa/s) & $+/+++$ & $++/++++$ & + \\
\hline Gelation methods & $\mathrm{CH}, \mathrm{PHCL}$ & CH, PHCL, SHTH, T & $\mathrm{CH}, \mathrm{PHCL}$ \\
\hline Cell viability & ++++ & $++/+++$ & +++ \\
\hline Cell densities & $++^{*}$ & $++++^{* *}$ & $t^{* * *}$ \\
\hline \multirow[t]{2}{*}{ Applications } & $\mathrm{B} / \mathrm{NB}$ & NB & $\mathrm{B} / \mathrm{NB}$ \\
\hline & $\begin{array}{c}\text { Cellularized skin construct, } \\
\text { medical devices }\end{array}$ & $\begin{array}{l}\text { Aortic valves, branched vascular } \\
\text { trees and tumour models }{ }^{23-24}\end{array}$ & $\begin{array}{l}\text { Layered cartilage and bone } \\
\text { constructs. }{ }^{26-27}\end{array}$ \\
\hline
\end{tabular}

Cell densities: ${ }^{*}>95 \%,{ }^{* *} 40-80 \%,{ }^{* * *}>85 \%$.

B: biological material; $\mathrm{CH}$ : chemical; NB: non-biological material; PHCL: photo-crosslinking; SHTH: sheer thinning; T: temperature.

integrity must not be altered or changed during printing or removal of sacrificial ink. With this method, high fidelity vascular channels with customizable designs can be fabricated. These biofabricated channels can be easily endothelized and perfused with cell culture media resulting in vascular channels ${ }^{31,32}$. A prototype using a naturally derived polysaccharide agarose as the sacrificial ink and GelMA as the main biomaterial; this sacrificial ink undergoes a complex process that permits pulling the agarose fibers form the scaffolds which form the perfusable micro-channels without a dissolution process $^{33}$. This prevents unnecessary osmotic damage to encapsulated cells and further interactions of dissolved sacrificial material that could potentially modify the structural properties of the main scaffolds ${ }^{34}$. Additionally, initial decreases in cell viability with indirect extrusion have been reported $(60-70 \%$ cell viability), but these printed cells proliferate over a course of one week into a $82 \%$ viability, probably attributed to the shear stress exerted during the printing process ${ }^{35}$.

2.Self-assembly of vessels: This is an alternative approach which relies in the endothelial cell ability to self-organize into blood vessels. In this case, cells are left and cultivated to form tubular channels. Efforts are focused in the direct control over the distribution and growth of vascular channels. One example is controlling the oxygen levels within the hydrogels to promote in-vitro tubulogenesis of endothelial-colony-forming- cells by activating hypoxia-inducible factors. Hence, in-vivo promotion of blood vessels recruitment and infiltration ${ }^{36}$. Early works with droplet-based direct extrusion demonstrated that the printed endothelial cells were able to proliferate and form a confluent lining along a fibrin scaffold.

At present, autonomous vascular structures use a single-step approach. Sheets of tissue produced by culturing SMCs along with fibroblasts on a gelatin coated tissue culture plate, were rolled onto a tubular support thus forming a vascular tubular construct with an internal smooth muscle layer and an external fibroblast layer which attempts to mimic the structure of tunica media and tunica adventitia. Self-assembly approach allowed the SMCs and fibroblasts to produce ECM which helps in determining mechanical properties of the assembled vascular construct. In fact, the fibroblast strain is decisive for its mechanical property. This was demonstrated with dermal fibroblasts which have denser and more compact ECM that results in higher mechanical strength and burst pressure. This promising model lacks the properties of the endothelial cells in the tunica intima which secrete transforming growth factors that promotes tissue homeostasis and regulates ECM degradation and production ${ }^{37}$.

This approach also uses LAB techniques as it allows specific deposition of individual cells. The 
velocity of this printing technique minimizes unnecessary damage to cells. In this case, LAB can print two distinct concentric circles, of human endothelial cells, in close proximity. Different types of cells with a high cell concentration can be printed according to a desired pattern with $L A B$ techniques, but, a certain level of artificial guidance, coupled with self-assembly of cells, could be the way ahead for fabrication of vascular constructs. One example is co-culturing HUVECs and printing them in close proximity to MSCs to enhance the stability of the newly formed vessels ${ }^{38}$.

Notably, reliance in cell based therapy is insufficient for promoting vasculogenesis and therefore, the micro-environment is essential for inducing self-assembly of vessels.

3. Scaffold free bio fabrication of autonomous vascular structures: This approach evolved because there is no scaffold which generates no or low inflammatory response in the host, degradation byproducts are toxic, degradation rates are no synchronous with tissue or vascular formations and they do not have mechanical properties similar to the native tissue. Also, scaffolds do not mimic the role in determining cellular activities of the native ECM. Investigations to fabricate vascular structures without scaffolds, opened the gate for small diameter blood vessel grafts rendering to biofabricate models with distinct tunica layers and higher mimicry ${ }^{39}$.

Multi-nozzle extrusion based techniques can be used to bio fabricate a tubular construct. The challenge of bioprinting autonomous vascular scaffolds lies in finding the proper concentration and viscosity of hydrogels with sufficient mechanical strength to support the weight of the entire structure ${ }^{40}$.

Droplet-based direct extrusion can also be used for autonomous vascular structures using SMCs encapsulated in sodium alginate into calcium chloride solutions. Constructs contracted in response to the vasoconstricting agonist Endothelin-1 in a dose dependent manner and, equivalently showed dilation of the lumen after agonists' removal. This printing technique is a promising alternative to overcoming limitations faced by scaffold-based engineering. Such a method has the potential to bio fabricate fine vascular structures with precise internal architectures even in a triple tunica layered perfusable vascular-like structure ${ }^{41,42}$.

This technique has been used not only to create structures $<6 \mathrm{~mm}$ but for creating macro-vascular structures, which mimic a real aorta imaged either by ACT or IRM in combination of novel computer aided algorithms. Mouse embryonic fibroblast (MEF) cell aggregates and support structures (hydrogels) are 3D bio printed layer-by-layer according to the proposed self-supported method to form an aortic tissue construct. The support structures are printed first, and then the cellular aggregates in order to prevent cell outflow and to preserve anatomically correct shape of the modeled vessel ${ }^{1}$.

Work still has to be done in order to increase the length of the construct and to ensure the sterile conditions and the viability after a long printing process.

\section{Challenges Associated with vessel Bioprinting}

Great challenges are faced when bioprinting a blood vessel; this may be partly explained by the more complex process of fabricating a hollow tube, compared to a two-dimensional tissue. This construction becomes more challenging when a multilayered impression is attempted, imitating the original structure of a blood vessel. We summarize some of the existing challenges in modern vascular bioprinting methods ${ }^{34-43}$ :

1. Creation of stable and viable vascular networks

a. Absence of mechanical and physical properties native of blood vessels

2.Biomaterial balance, toxicity and degradability

3. Limitations in sub-micron capillary printing

a.Poor patency rates due to their thrombogenicity

4. Bioprinting limitations

a. Creation of concomitant nerve supply networks

b. Single bioprinting is insufficient due to failure to provide desired mechanical properties

c. Constant reproducibility

d. Self-assembly approach: direct control over distribution and growth of vascular channels

5. Lack of common tissue engineering methods and evaluation criteria

6. Restrictions in biodegradable and/or biocompatible resins

a. FDA approval

7. Difficulties with in vivo testing of bio-constructs

Further information regarding these topics is explained with more detail in the rest of the contents of this chapter.

\section{Applications of 3D bioprinting in vascular surgery training}

Education and training is another fundamental application of 3D printing and modeling. 3D printing allows 


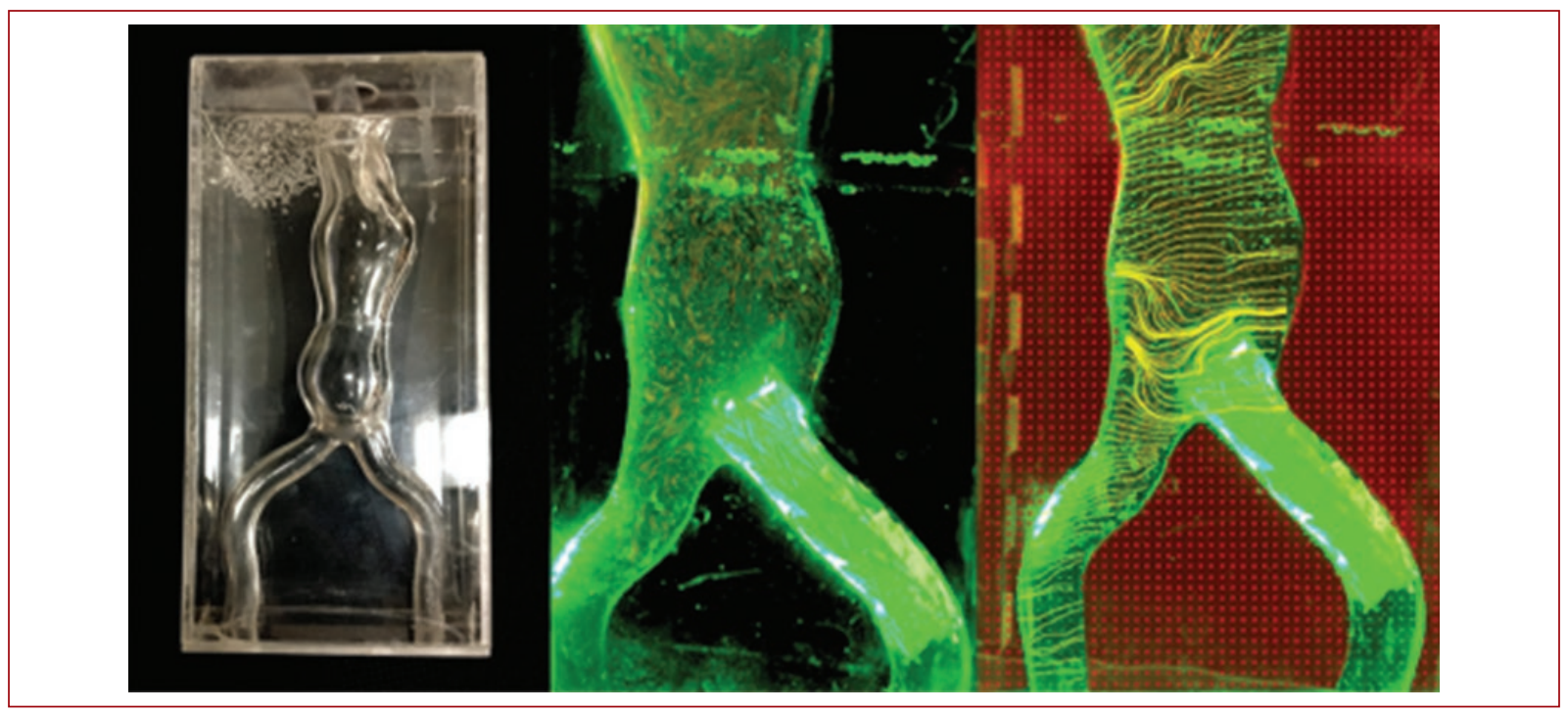

Figure 3. Three-dimensional printed aortic aneurysm model. This is a rapid prototyping technique to enable endovascular aneurysm repair planning for surgical trainees more effectively and also analysis of flow dynamics within the aortic aneurysm.

the creation of multiple human structures to provide a hands-on approach. The development of anatomical knowledge in the clinical and surgical context is essential for medical students, residents and trainees. Recently published research by Jones et $\mathrm{al}^{44}$ studied the feasibility of creating anatomical 3D models from digital images and its potential opportunities to enhance surgical education and clinical practice. In the survey, $90 \%$ of the participants slightly or strongly agreed that the 3D models would help teach basic anatomy, and all participants believed the models would favor the medical school curriculum.

Rapid prototyping has become an extremely useful tool in the field of vascular surgery too. It has taken its place in anatomic modeling and implant perspectives. Vascular devices have the potential to be 3D printed to contribute to improve patient outcomes. Endovascular procedures require intense training and repetition. Students and residents constantly learn these procedures in patient based training programs. Virtual reality and cadaveric simulations have been educationally validated, however, these teaching methods have shown to be expensive and often unrealistic. 3D endovascular simulators have been created to provide students, residents and physicians with simple, low cost, maintenance free, realistic and reproducible teaching models.

Mafeld S, et al. ${ }^{45}$ provided the first example of its kind by evaluating the feasibility of 3D printing an anatomically accurate human aorta for the purposes of endovascular training. The endovascular tasks performed with the 3D printed simulator included the review of common catheter shapes, access to aortic branch vessels and crossover of aortic bifurcation. The 3D model allowed participants to experience wire skills such as pushability, torquability and trackability.

3D-printed models in vascular surgery allow realistic surgical simulation and the visualization of challenging anatomy in open and endovascular procedures. These characteristics allow also real life pre-operative planning, customizable implants, improved patient outcomes and increased operative effectiveness, as reported by Matthew et al ${ }^{46}$ who selected an endoprothesis for an abdominal aortic aneurysm with complex neck anatomy based on a 3D printed model (Fig. 3).

Surgical simulation will find its widespread applicability for skill acquisition and device training in a safe, patient-risk free environment. Costs, regulations and further research with high quality evidence need to be addressed before 3D-printed models can become a part of everyday practice ${ }^{47}$.

\section{Future of blood vessel bioprinting}

Blood vessel bioprinting remains to be the second tissue ranked in $3 \mathrm{D}$ bioprinting complexity just after two-dimensional impressions. Hollow organs follow the complexity order, being the solid organ construction the least the most complicated ${ }^{48}$. Achieving this final objective, requires the production of capillary structures 
to provide the elements and compounds for its maintenance, growth and function.

Capillaries and micro vessels required for tissue perfusion and macro vessels with suitable mechanical properties for physiological pressures during the cardiac cycle, which are also suitable for surgical connection, are the goals to be addressed.

Efforts to design computer-aided microvasculature systems for use in vascular scaffold production are already in progress by means of stereolithographic micro-computer tomographic 3D models. This technique enables to mimic the design of vascular tree systems containing capillary beds found in tissues, for example, in the design development of capillary-containing vascular tree scaffolding for skin $^{49}$.

On the other hand, the future of blood vessel bioprinting has demonstrated promising results when applying a hybrid technique for creating a vascular graft. The resulting scaffold showed better mechanical properties while preserving an optimal fibrillar arrangement for initial cell attachment favoring also the differentiation process towards vascular endothelium of the MSCs seeded ${ }^{50}$.

Besides from the fabrication of the multi-scalar nature from the large arteries to the sub-micron capillaries and to the venous systems, the fabrication of the intricate nerve supply networks intimately connected to our vascular system, remains to be replicated in order to complete the vessel physiology. This ultimate goal may be possible by using 4D bioprinting, where "time" is integrated with 3D bioprinting as the fourth dimension and the printed constructs are able to evolve over time after being printed, alter their shapes and functionalities in response to external stimuli ${ }^{51}$.

Future bio-inks developments and innovations on technology of the bioprinting systems are continuously in progress to overcome the limitations for treating vascular disease in terms of graft availability and also for organ transplantation. These objectives required the continuous participation of a multidisciplinary team to produce a complete bio-compatible construct.

An expedite promising vascular tissue constructions may be achieved by the efficient and effective stimulation of bioreactors. Also, the time-consuming expansion period is reduced when automated cell culture systems are combined with bioreactors ${ }^{14}$.

\section{Acknowledgments}

Dr. Rodrigo Lozano-Corona and Dr. Javier E. Anaya-Ayala.

\section{Funding}

CONACyT, Innovation Stimulus Program.

\section{Conflicts of interest}

The authors declare no conflict of interests.

\section{Ethical diclosures}

Protection of human and animal subjects. The authors declare that no experiments were performed on humans or animals for this study.

Confidentiality of data. The authors declare that they have followed the protocols of their work center on the publication of patient data.

Right to privacy and informed consent. The authors declare that no patient data appear in this article.

\section{References}

1. Kucukgul C, Ozler SB, Inci I, Karakas E, Irmak S, Gozuacik D, et al. 3D bioprinting of biomimetic aortic vascular constructs with self-supporting cells: 3D Bioprinting of Biomimetic Aortic Vascular Constructs. Biotechnology and Bioengineering. $2015 \mathrm{Apr} ; 112(4): 811-21$.

2. Klinkert P, Post P., Breslau P., van Bockel J. Saphenous Vein Versus PTFE for Above-Knee Femoropopliteal Bypass. A Review of the Literature. European Journal of Vascular and Endovascular Surgery. 2004 Apr;27(4):357-62.

3. Conte MS. The ideal small arterial substitute: a search for the Holy Grail? The FASEB Journal. 1998 Jan;12(1):43-5.

4. Ross MH, Pawlina W. Cardiovascular System. In: Histology a Text and Atlas with Correlated Cell and Molecular Biology. $7^{\text {th }}$ Edition. Lippincott Williams \& Wilkins. Philadelphia, EUA. 2016

5. Tai NR, Salacinski HJ, Edwards A, Hamilton G, Seifalian AM. Compliance properties of conduits used in vascular reconstruction. British Journal of Surgery. $2000 \mathrm{Nov} ; 87(11): 1516-24$.

6. Murphy SV, Atala A. 3D bioprinting of tissues and organs. Nature Biotechnology. 2014 Aug;32(8):773-85.

7. Ingber DE, Mow VC, Butler D, Niklason L, Huard J, Mao J, et al. Tissue Engineering and Developmental Biology: Going Biomimetic. Tissue Engineering. $2006 \mathrm{Dec} ; 12(12): 3265-83$.

8. Marga F, Neagu A, Kosztin I, Forgacs G. Developmental biology and tissue engineering. Birth Defects Research Part C: Embryo Today: Reviews. 2007 Dec;81(4):320-8.

9. Mironov V, Visconti RP, Kasyanov V, Forgacs G, Drake CJ, Markwald RR. Organ printing: Tissue spheroids as building blocks. Biomaterials. 2009 Apr;30(12):2164-74.

10. Kelm JM, Lorber V, Snedeker JG, Schmidt D, Broggini-Tenzer A Weisstanner $M$, et al. A novel concept for scaffold-free vessel tissue engineering: Self-assembly of microtissue building blocks. Journal of Biotechnology. 2010 Jul 1:148(1):46-55.

11. Alajati A, Laib AM, Weber $H$, Boos AM, Bartol A, Ikenberg $K$, et al. Spheroid-based engineering of a human vasculature in mice. Nature Methods. 2008 May;5(5):439-45.

12. Ravi S, Chaikof EL. Biomaterials for vascular tissue engineering. Regenerative Medicine. 2010 Jan;5(1):107-20.

13. Zuk PA, Zhu M, Ashjian P, De Ugarte DA, Huang JI, Mizuno $\mathrm{H}$, et al. Human Adipose Tissue Is a Source of Multipotent Stem Cells. Raff M, editor. Molecular Biology of the Cell. 2002 Dec;13(12):4279-95.

14. Nemeno-Guanzon JG, Lee S, Berg JR, Jo YH, Yeo JE, Nam BM, et al. Trends in Tissue Engineering for Blood Vessels. Journal of Biomedicine and Biotechnology. 2012;2012:1-14.

15. Wang C, Cen L, Yin S, Liu Q, Liu W, Cao Y, et al. A small diameter elastic blood vessel wall prepared under pulsatile conditions from polyglycolic acid mesh and smooth muscle cells differentiated from adipose-derived stem cells. Biomaterials. 2010 Feb;31(4):621-30.

16. Murphy SV, Atala A. 3D bioprinting of tissues and organs. Nature Biotechnology. 2014 Aug;32(8):773-85

17. Xu T, Kincaid H, Atala A, Yoo JJ. High-Throughput Production of Single-Cell Microparticles Using an Inkjet Printing Technology. Journal of Manufacturing Science and Engineering. 2008;130(2):021017. 
18. Tasoglu S, Demirci U. Bioprinting for stem cell research. Trends in Biotechnology. 2013 Jan;31(1):10-9.

19. Jakab K, Damon B, Neagu A, Kachurin A, Forgacs G. Three-dimensional tissue constructs built by bioprinting. Biorheology. 2006:43(3,4):509-13.

20. Visser J, Peters B, Burger TJ, Boomstra J, Dhert WJA, Melchels FPW et al. Biofabrication of multi-material anatomically shaped tissue constructs. Biofabrication. 2013 Jul 2;5(3):035007.

21. Guillotin B, Souquet A, Catros S, Duocastella M, Pippenger B Bellance $S$, et al. Laser assisted bioprinting of engineered tissue with high cell density and microscale organization. Biomaterials. 2010 Oct;31(28):7250-6.

22. Michael S, Sorg H, Peck C-T, Koch L, Deiwick A, Chichkov B, et al. Tissue Engineered Skin Substitutes Created by Laser-Assisted Bioprinting Form Skin-Like Structures in the Dorsal Skin Fold Chamber in Mice. Slominski AT, editor. PLoS ONE. 2013 Mar 4;8(3):e57741.

23. Duan B, Hockaday LA, Kang KH, Butcher JT. 3D Bioprinting of heterogeneous aortic valve conduits with alginate/gelatin hydrogels. Journal of Biomedical Materials Research Part A. 2013 May;101A(5):1255-64.

24. Norotte C, Marga FS, Niklason LE, Forgacs G. Scaffold-free vascular tissue engineering using bioprinting. Biomaterials. 2009 Oct;30(30):5910-7.

25. Xu F, Celli J, Rizvi I, Moon S, Hasan T, Demirci U. A three-dimensional in vitro ovarian cancer coculture model using a high-throughput cell patterning platform. Biotechnology Journal. 2011 Feb;6(2):204-12.

26. Xu T, Binder KW, Albanna MZ, Dice D, Zhao W, Yoo JJ, et al. Hybrid printing of mechanically and biologically improved constructs for cartilage tissue engineering applications. Biofabrication. 2012 Nov 21 5(1):015001.

27. De Coppi P, Bartsch G, Siddiqui MM, Xu T, Santos CC, Perin L, et al. Isolation of amniotic stem cell lines with potential for therapy. Nat Biotechnol. 2007 Jan;25(1):100-6.

28. Koike N, Fukumura D, Gralla O, Au P, Schechner JS, Jain RK. Creation of long-lasting blood vessels: Tissue engineering. Nature. 2004 Mar; 428(6979):138-9.

29. Gao Q, He Y, Fu J, Liu A, Ma L. Coaxial nozzle-assisted 3D bioprinting with built-in microchannels for nutrients delivery. Biomaterials. 2015 Aug;61:203-15.

30. Shengjie Li, Zhuo Xiong, Xiaohong Wang, Yongnian Yan, Haixia Liu Renii Zhang. Direct Fabrication of a Hybrid Cell/Hydrogel Construct by a Double-nozzle Assembling Technology. Journal of Bioactive and Compatible Polymers. 2009 May;24(3):249-65

31. Kolesky DB, Truby RL, Gladman AS, Busbee TA, Homan KA, Lewis JA 3D Bioprinting of Vascularized, Heterogeneous Cell-Laden Tissue Constructs. Advanced Materials. 2014 May:26(19):3124-30.

32. Wu W, DeConinck A, Lewis JA. Omnidirectional Printing of 3D Microvas cular Networks. Advanced Materials. 2011 Jun 24;23(24):H178-83.

33. Bertassoni LE, Cecconi M, Manoharan V, Nikkhah M, Hjortnaes J, Cristino AL, et al. Hydrogel bioprinted microchannel networks for vascularization of tissue engineering constructs. Lab Chip. 2014;14(13):2202-11.

34. Ng HY, Lee K-XA, Kuo C-N, Shen Y-F. Bioprinting of artificial blood vessels. International Journal of Bioprinting [Internet]. 2018 Jun 19 [cited 2018 Oct 31;4(2). Available from: http://ijb.whioce.com/index.php/int-j-bioprinting/article/view/140.

35. Smith CM, Christian JJ, Warren WL, Williams SK. Characterizing Environmental Factors that Impact the Viability of Tissue-Engineered Constructs Fabricated by a Direct-Write Bioassembly Tool. Tissue Engineering. $2007 \mathrm{Feb} ; 13(2): 373-83$
36. Park KM, Gerecht S. Hypoxia-inducible hydrogels. Nature Communications [Internet]. 2014 Dec [cited 2018 Nov 29;5(1). Available from: http:// www.nature.com/articles/ncomms5075

37. Gauvin $R$, Ahsan $T$, Larouche $D$, Lévesque $P$, Dubé J, Auger FA, et al. A Novel Single-Step Self-Assembly Approach for the Fabrication of Tissue-Engineered Vascular Constructs. Tissue Engineering Part A. 2010 May;16(5):1737-47.

38. Wu PK, Ringeisen BR. Development of human umbilical vein endothelial cell (HUVEC) and human umbilical vein smooth muscle cell (HUVSMC) branch/stem structures on hydrogel layers via biological laser printing (BioLP). Biofabrication. 2010 Mar 1;2(1):014111.

39. Zhang Y, Yu Y, Ozbolat IT. Direct Bioprinting of Vessel-Like Tubular Microfluidic Channels. Journal of Nanotechnology in Engineering and Medicine. 2013 Jul 23;4(2):020902.

40. Tan EYS, Yeong WY. Concentric Bioprinting Of Alginate-Based Tubular Constructs Using Multi-Nozzle Extrusion-Based Technique. International Journal of Bioprinting [Internet]. 2015 Jul 2 [cited 2018 Nov 29; Available from: http://ijb.whioce.com/index.php/int-j-bioprinting/article/view/01003.

41. Liou J-C, Tseng F-G. Three-Dimensional Architecture of Multiplexing Data Registration Integrated Circuit for Large-Array Ink Jet Printhead. Journal of Imaging Science and Technology. 2008:52(1):010508.

42. Hasan A, Paul A, Memic A, Khademhosseini A. A multilayered microfluidic blood vessel-like structure. Biomedical Microdevices [Internet]. 2015 Oct [cited 2018 Nov 29;17(5). Available from: http://link.springer. com/10.1007/s10544-015-9993-2

43. Chia HN, Wu BM. Recent advances in $3 D$ printing of biomaterials. Journal of Biological Engineering [Internet]. 2015 Dec [cited 2018 Nov 29;9(1). Available from: http://www.jbioleng.org/content/9/1/4.

44. Jones DB, Sung R, Weinberg C, Korelitz T, Andrews R. Three-Dimensional Modeling May Improve Surgical Education and Clinical Practice. Surgical Innovation. 2016 Apr;23(2):189-95.

45. Mafeld S, Nesbitt $C$, McCaslin J, Bagnall A, Davey $P$, Bose $P$, et al Three-dimensional (3D) printed endovascular simulation models: a feasibility study. Annals of Translational Medicine. 2017 Feb;5(3):42-42.

46. Tam MDBS, Laycock SD, Brown JRI, Jakeways M. 3D Printing of an Aortic Aneurysm to Facilitate Decision Making and Device Selection for Endovascular Aneurysm Repair in Complex Neck Anatomy. Journal of Endovascular Therapy. 2013 Dec;20(6):863-7.

47. Kurenov SN, Ionita C, Sammons D, Demmy TL. Three-dimensional printing to facilitate anatomic study, device development, simulation, and planning in thoracic surgery. The Journal of Thoracic and Cardiovascular Surgery. 2015 Apr;149(4):973-979.e1.

48. Zopf DA, Hollister SJ, Nelson ME, Ohye RG, Green GE. Bioresorbable Airway Splint Created with a Three-Dimensional Printer. New England Journal of Medicine. 2013 May 23;368(21):2043-5.

49. Mondy WL, Cameron D, Timmermans J-P, De Clerck N, Sasov A Casteleyn C, et al. Computer-aided design of microvasculature systems for use in vascular scaffold production. Biofabrication. 2009 Sep 1;1(3):035002.

50. Centola M, Rainer A, Spadaccio C, De Porcellinis S, Genovese JA, Trombetta $\mathrm{M}$. Combining electrospinning and fused deposition modeling for the fabrication of a hybrid vascular graft. Biofabrication. 2010 Mar 1;2(1):014102.

51. Ng HY, Lee K-XA, Kuo C-N, Shen Y-F. Bioprinting of artificial blood vessels. International Journal of Bioprinting [Internet]. 2018 Jun 19 [cited 2018 Nov 29;4(2). Available from: http://ijb.whioce.com/index.php/int-jbioprinting/article/view/140 